\title{
COVID-19 pandemic: How close are we for an effective therapy?
}

Roy B

\section{Corresponding author:}

Dr. Bedanta Roy,

Senior Lecturer, Department of Physiology, Faculty of Medicine, Quest International University, Ipoh, Perak, Malaysia

Email: bedanta.roy@gmail.com ORCID

\section{Information about the article:}

Published online: June 30, 2020

Cite this article:

Roy B. COVID-19 pandemic: How close are we for an effective therapy? Journal of Biomedical Sciences. 2020;7(1):1-3

\section{Publisher}

Nepal Health Research Society, Bahundhara -6, Gokarnesowor Municipality, Kathmandu, Nepal eISSN 2382-5545, ISSN 2676-1343 (Print)

(C) The Author(s). 2020

Content licensing: CC BY 4.0
Coronaviruses are a type of RNA virus found in avis, mammals, and humans, causing upper-respiratory tract infections. In humans infection in the respiratory system can range from mild to lethal [1]. Six major types of viruses affecting humans are documented. Among these six members, four (HKU1, 229E, NL63, and OC43) cause cold and flu like symptoms [2], while rest two are responsible for severe acute respiratory syndrome (SARS-Coronavirus) and Middle East respiratory syndrome coronavirus (MERS-CoV) [3]. There is a high probability of coronavirus pandemic recurrence because of it's zoonotic nature and the genetic variation [4]. COVID-19 is spreading quickly across the globe, but unfortunately, we have only limited specific tools for controlling and managing this ongoing epidemic. Most countries follow the same quarantine strategy, isolation, and social distancing to prevent the disease spread and care for the sick.

No SARS-CoV-2 treatment is officially endorsed, but already approved medicines are being investigated for the efficacy in various clinical trials. Nucleoside analogs, interferon, plays an immune modulatory role and commonly used drugs for malaria with antiviral activity like chloroquine/hydroxychloroquine we are using as a treatment option.

\section{Antiviral drugs}

The prime target for ribavirin, favipiravir, galidesivir, and remdesivir is the RNA dependent RNA polymerase (RdRp) enzyme to restrict viral RNA synthesis [5]. Favipiravir inhibits RNA-dependent RNA polymerase of influenza virus, hence an effective choice of treatment for influenza [6]. So, clinical trials are on a full swing with a combination of favipiravir and interferon- $\alpha 12$ and a combination of novel inhibitors of the influenza RNA replication namely favipiravir and baloxavir marboxil by targeting different protein subunits of the influenza polymerase complex to determine the efficacy as a choice of treatment [7].

Although ribavirin is a well-known derivative antiviral drug approved for the treatment of hepatitis $\mathrm{C}$ virus $(\mathrm{HCV})$ and respiratory syncytial virus (RSV), in higher doses, it causes anemia. So, it's efficacy and uses for the treatment of coronavirus is questionable [8]. Remdesivir a prodrug of a nucleotide analogue, can be used to treat filoviruses, paramyxoviruses, pneumoviruses, and coronaviruses $[9,10]$. 
Recent studies have shown a promising result of Remdesivir administration in SARS-CoV-2 patients with a high recovery rate $[11,12]$. Phase-III clinical trials have recently undergone to assess the effectiveness of remdesivir as $200 \mathrm{mg}$ OD (loading dose) and $100 \mathrm{mg}$ OD (maintenance doses) for nine days. [13]. lopinavir and ritonavir two well-known HIV protease inhibitors; whose activity was in the limelight during SARS and MERS outbreaks [14, 15]. Combination therapy of these two drugs, which increases drug bioavailability, probably inhibits the chymotrypsin-like protease of MERS, and SARS is currently under trial against SARS-CoV-2 [16]. Why are we attracted to this combination therapy? The answer is the wide availability, and it is manufacturable to scale, so a prime choice for the clinicians. Ample case reports and case series are published to support it. Still, a million-dollar question can be raised towards its trustworthiness.

Promising results came using a combination of Remdesivir and chloroquine in a study with infected Vero E6 cells with SARS-CoV-2. EC90 value of Remdesivir was obtained $1.76 \mu \mathrm{M}$ [11]. A randomized clinical trial on lopinavir-ritonavir from Wuhan, the first epicenter of COVID-19 pandemic was done early in this year [17]. Unfortunately, the trial results were disappointing and concluded with no benefit beyond standard care. The reason may be due to the study population's choice who was already in an advanced stage of infection with substantial tissue damage. Oseltamivir was administered orally, because this drug was effective during MERS-COV outbreak. In China, suspected cases of COVID-19 infection were treated with oral oseltamivir, which had success in history during the MERS-COV outbreak.

\section{Chloroquine and hydroxychloroquine}

Chloroquine is a small molecular weight 4aminoquinoline with antimalarial, anti-inflammatory activities. It has a strong inhibitory potential against SARS-CoV-2 (EC50 $=1.14 \mu \mathrm{M}$ in Vero E6 cells) [11]. Discovered in 1960, the antiviral activity of this antimalarial drug was reported against SARS, enterovirus, and Zika virus. Mechanism of action includes an increase in endosomal $\mathrm{pH}$ followed by blocked viral cell fusion of SARS-CoV-2 with the host cell and interference with glycosylation of angiotensin-converting enzyme receptors (ACE-2 receptors). Hence viral attachment and replication is stopped [18]. Although recent evidence of the reduced duration of the disease and diminished pneumonia symptoms was observed by administering chloroquine phosphate in SARS-CoV-2 patients [19], but FDA warned against the use of hydroxychloroquine or chloroquine for COVID-19 treatment due to the risk of heart rhythm problems [20].

\section{Chymotrypsin-like inhibitors}

This is a serotonin antagonist was tested in humans in the 1960s, and research-documented it's inhibitory action on 3CL proteinase thereby inhibition of SARS$\mathrm{CoV}$ replication and shown promising results [21].

Clinical trials are ongoing worldwide; in the meantime, there are changes in the guidelines. Some of the trials still need to be passed through many hurdles, and it is not very clear how quickly we will find a suitable answer.

\section{Dr. Bedanta Roy}

Deputy Editor,

Journal of Biomedical Sciences

\section{Keywords}

Antiviral, chloroquine, drug, infection, SARS-CoV-2, treatment, trials, virus

\begin{abstract}
Abbreviations
Coronavirus disease (COVID-19), Severe acute respiratory syndrome (SARS-Coronavirus) Severe acute respiratory syndrome coronavirus 2 (SARS-Cov-2), Middle East respiratory syndrome coronavirus (MERS-CoV)
\end{abstract}

\section{Availability of data and materials}

Not applicable.

\section{Competing interests}

None declared.

\section{Publisher's Note}

NHRS remains neutral with regard to jurisdictional claims in published maps and institutional affiliations.

The publisher shall not be legally responsible for any types of loss, actions, claims, proceedings, demand or costs or damages whatsoever or howsoever caused arising directly or indirectly in connection with or arising out of the use of this material.

\section{Author information}

Dr. Bedanta Roy, Senior Lecturer, Department of Physiology, Faculty of Medicine, Quest International University, Ipoh, Perak, Malaysia ORCID

\section{References}

1. Weiss SR, Leibowitz JL. Coronavirus pathogenesis. Adv Virus Res. 2011;81:85-164. https://doi.org/10.1016/B978-0-12-385885$\underline{6.00009-2}$

2. Su S, Wong G, Shi W, Liu J, Lai ACK, Zhou J, et al. Epidemiology, genetic recombination, and pathogenesis of coronaviruses. Trends Microbiol. 2016;24(6):490-502. 
https://doi.org/10.1016/j.tim.2016.03.003

3. Cui J, Li F, Shi Z-L. Origin and evolution of pathogenic coronaviruses. Nat Rev Microbiol. 2019;17(3):181-92. https://doi.org/10.1038/s41579-018-0118-9

4. 4. Wong G, Liu W, Liu Y, Zhou B, Bi Y, Gao GF. MERS, SARS, and Ebola: the role of super-spreaders in infectious disease. Cell Host Microbe. 2015;18(4):398-401.

https://doi.org/10.1016/j.chom.2015.09.013

5. De Clercq E. New nucleoside analogues for the treatment of hemorrhagic fever virus infections. Chem Asian J. 2019;14(22):3962-8.

https://doi.org/10.1002/asia.201900841

6. Holshue ML, DeBolt C, Lindquist S, Lofy KH, Wiesman J, Bruce $\mathrm{H}$, et al. Washington State 2019-nCoV Case Investigation Team. First case of 2019 novel coronavirus in the United States. N Engl J Med. 2020;382:929-36.

https://doi.org/10.1056/NEJMoa2001191

7. Qiu Yunqing WL. Registry CCT. A randomized controlled trial for the efficacy and safety of Baloxavir Marboxil, Favipiravir tablets in 2019nCoV pneumonia (novel coronavirus pneumonia, NCP) patients who are still positive on virus detection under the current antiviral therapy [Accessed 27/06/2020]. Available from: URL: http://www.chictr.org.cn/hvshowproject.aspx?id= $\underline{22227]}$

8. Zumla A, Chan JFW, Azhar EI, Hui DSC, Yuen KY. Coronaviruses-drug discovery and therapeutic options. Nat Rev Drug Discov. 2016;15(5):327-47.

https://doi.org/10.1038/nrd.2015.37

9. Lo MK, Jordan R, Arvey A, Sudhamsu J, Shrivastava-Ranjan P, Hotard AL, et al. GS-5734 and its parent nucleoside analog inhibit filo-, pneumo-, and paramyxoviruses. Sci Rep. 2017; 743395

https://doi.org/10.1038/srep43395

10. Sheahan TP, Sims AC, Graham RL, Menachery VD, Gralinski LE, Case JB, et al. Broadspectrum antiviral GS-5734 inhibits both epidemic and zoonotic coronaviruses. Sci Transl Med. 2017; 9eaal3653

https://doi.org/10.1126/scitranslmed.aal3653

11. Wang M, Cao R, Zhang L, Yang X, Liu J, Xu M, et al. Remdesivir and chloroquine effectively inhibit the recently emerged novel coronavirus (2019-nCoV) in vitro. Cell Res. 2020;30(3):269-71. https://doi.org/10.1038/s41422-020-0282-0

12. Wang Y, Zhang D, Du G, Du R, Zhao J, Jin Y, et al. Remdesivir in adults with severe COVID-19: a randomised, double-blind, placebo-controlled, multicentre trial. The Lancet. 2020;395(10236):1569-78

13. Bin Cao YW. Mild/Moderate 2019-nCoV Remdesivir RCT Available from https://clinicaltrials.gov/ct2/show/NCT04252664

14. Chu C, Cheng VC, Hung IF, K Chan, R Kao, L Poon, et al. HKU/UCH SARS Study Group. Role of lopinavir/ritonavir in the treatment of SARS: initial virological and clinical findings. Thorax. 2004;59(3):252-6.

https://doi.org/10.1136/thorax.2003.012658

15. Chan JF-W, Yao Y, Yeung ML, et al. Treatment with lopinavir/ritonavir or interferon- $\beta 1 \mathrm{~b}$ improves outcome of MERS-CoV infection in a nonhuman primate model of common marmoset. J Infect Dis. 2015;212(12):1904-13. https://doi.org/10.1093/infdis/jiv392

16. De Clercq E, Li G. Approved antiviral drugs over the past 50 years. Clin Microbiol Rev. 2016;29(3):695-747. https://doi.org/10.1128/CMR.00102-15

17. Cao B, Wang Y, Wen D, Liu W, Wang J, Fan G, et al. A trial of lopinavir-ritonavir in adults hospitalized with severe COVID-19. N Engl J Med 2020;382:1787-99.

https://doi.org/10.1056/NEJMoa2001282

18. Vincent MJ, Bergeron E, Benjannet S, Erickson BR, Rollin PE, Ksiazek TG, et al. Chloroquine is a potent inhibitor of SARS coronavirus infection and spread. Virol J. 2005;2(1):69.

https://doi.org/10.1186/1743-422X-2-69

19. Gao J, Tian Z, Yang X. Breakthrough: Chloroquine phosphate has shown apparent efficacy in treatment of COVID-19 associated pneumonia in clinical studies. BioSci Trends. 2020;14(1):72-3. https://doi.org/10.5582/bst.2020.01047

20. Food and Drug Administration. FDA cautions against use of hydroxychloroquine or chloroquine for COVID-19 outside of the hospital setting or a clinical trial due to risk of heart rhythm problems. 2020. [Accessed on 28/06/2020] Available from: URL: https://www.fda.gov/drugs/drug-safety-andavailability/fda-cautions-against-usehydroxychloroquine-or-chloroquine-covid-19outside-hospital-setting-or

21. Chen L, Gui C, Luo X, Yang Q, Günther S, Scandella E, et al. Cinanserin Is an Inhibitor of the 3C-Like Proteinase of Severe Acute Respiratory Syndrome Coronavirus and Strongly Reduces Virus Replication In Vitro. Journal of Virology. 2005;79(11):7095-103. 